\title{
Mathematics Curriculum Framework for Early Childhood Education Based on Science, Technology, Engineering and Mathematics (STEM)
}

\author{
Muhammad Nasiru Hassan ${ }^{1 *}$, Abdul Halim Abdullah ${ }^{2}$, Norulhuda Ismail ${ }^{2}$, \\ Siti Norbazilah Ahmad Suhud ${ }^{2}$, Mohd Hilmi Hamzah ${ }^{3}$ \\ ${ }^{1}$ Sokoto State University, NIGERIA \\ ${ }^{2}$ School of Education, Universiti Teknologi Malaysia (UTM), MALAYSIA \\ ${ }^{3}$ School of Languages, Civilisation and Philosophy, UUM College of Art and Science, Universiti Utara Malaysia, MALAYSIA \\ *CORRESPONDENCE: $\square$ mohammad.nasiruhassan@ssu.edu.ng
}

\begin{abstract}
Background: Nowadays, the attention to integrate Science, Technology, Engineering and Mathematics (STEM) education to the existing curriculum is widely increasing around the world. In the early childhood education settings, many researchers have discussed the importance of early introduction to STEM education for children. However, the initiatives for curriculum development, teacher's preparation and standardisation in the early childhood setting are still limited in Malaysia. Therefore, this study aims to develop mathematics curriculum framework and activities for early childhood education based on STEM specifically for three- to four-year old children. In this study, the mathematics curriculum frameworks and activities based on STEM were developed according to the ADDIE model. A total of eight respondents consisting of experts and teachers participated in this study. The evaluation forms were distributed to the respondents to gather their feedback on the developed mathematics curriculum framework and activities for early childhood education based on STEM

Results: From the data obtained, it can be concluded that the respondents give positive feedback on the developed mathematics curriculum framework and activities. However, there are still some rooms for improvement, the comments and recommendations from the respondents that will be used for future improvement of the developed products.

Conclusions: Hence, from this study, it is hoped that more efforts and studies could be conducted by many parties to promote STEM in early childhood education.
\end{abstract}

Keywords: mathematics curriculum framework, early childhood education, STEM

\section{INTRODUCTION}

Education plays an important role in nurturing children. A high-quality education is crucial in developing individuals who are prepared for the challenges of globalisation. Studies have shown that early childhood is a fundamental stage in education. Early childhood is the formative period which includes critical stages in the development of an individual. Given this fact, research on children's learning in the first six years of their life has demonstrated the importance of early experiences in mathematics. A joint statement by the National Council of Teachers of Mathematics (NCTM) and the National Association for the Education of Young Children (NAEYC) (adopted 2002, updated in 2010) highlights that "a high-quality, challenging, and accessible

Article History: Received 24 July 2018 Revised 17 October $2018 \bullet$ Accepted 6 November 2018

(C) 2019 by the authors; licensee Modestum Ltd., UK. Open Access terms of the Creative Commons Attribution 4.0 International License (http://creativecommons.org/licenses/by/4.0/) apply. The license permits unrestricted use, distribution, and reproduction in any medium, on the condition that users give exact credit to the original author(s) and the source, provide a link to the Creative Commons license, and indicate if they made any changes. 
mathematics education for three- to six-year old children is a vital foundation for future mathematics learning". Therefore, introducing mathematics as early as three years old is crucial for children in helping them make sense of real-world situations and construct a solid foundation for success in primary schools.

Malaysia has taken steps to prepare for the aforementioned challenges by introducing Science, Technology, Engineering and Mathematics (STEM) in the Malaysia Education Blueprint (2013-2015). According to Sneideman (2013), STEM is a philosophy or a way of thinking in which Science, Technology, Engineering, and Mathematics are integrated or combined into one field of education that encourages students to think in a more connected and holistic way. This is because STEM education emphasises aspects of reality and practicality in which students are able to learn Science and Mathematics through the application of technology and engineering in real, realistic, and meaningful ways. Furthermore, studies have shown that children's earliest experiences with science, technology, engineering, and mathematics will predict future engagement and success in these fields. A high-quality STEM experiences may provide engagement, confidence, curiosity, and understanding for younger students towards the integrated STEM disciplines. In addition, according to a policy report by the Early Childhood STEM Working Group (2017), providing positive opportunities from early years is crucial in nurturing young students' attitudes and beliefs on their ability to succeed in STEM fields. These positive experiences help children develop dispositions such as curiosity, imagination, flexibility, inventiveness, and persistence which contribute to their future success beyond the school environment. At the same time, the country's goal in developing workforce for STEM-related careers - such as scientists, engineers, mathematicians, and technologists - can be achieved.

\section{RESEARCH BACKGROUND}

Nordin (2012) reveals that, in Malaysia, students' enrolment in the science stream has dropped in 2012 to as low as 29\%. Based on the Science and Technology in Human Capital Report and Science Outlook by the National Academy of Science (2015), the country needs at least 270,000 science-stream students sitting for the Malaysian Certificate of Education (SPM) examination annually. However, to date, there are approximately 90,000 students who take up the science stream. It seems that Malaysia still has a long way to go before reaching the target ratio of 60:40 for the number of students enrolling in STEM versus non-STEM programmes at the tertiary level. In the future, if the same situation persists, Malaysia will face a serious shortage of human capital in the science fields as the students' enrolment target is not met annually at both primary and tertiary levels. Besides the reduced number of students' enrolment in the science stream, the lack of mathematics skills among Malaysian students is also worrying. This can be observed in the below-average achievement of Malaysian students in the Trends in International Mathematics and Science Study (TIMSS) 2015 assessment and the Programme for International Student Assessment (PISA) 2015. According to the Malaysian Ministry of Education (2013), 30\% of the questions in TIMSS are knowledge-level questions and $35 \%$ are analysis-level and reasoning questions. This shows that more than half of the questions include Higher-Order Thinking Skills (HOTS). Based on the result of these assessments, it can be seen that Malaysian students are less exposed to HOTS questions which involve non-routine and open-ended problems. It seems that the students face difficulties in terms of reasoning and connecting the knowledge that they have learned.

In addition, a report by the Malaysian Ministry of Science, Technology, and Innovation (2008) reveals that more than one-third of Malaysian students express a lack of interest in Science and Technology. Moreover, Ali (2012) asserts that "though the sustenance of competitive advantage of nations depends more and more on science and engineering, our primary and secondary schools seem to have a limitation in producing enough students with the interest, motivation, and skills they need". Hence, to achieve one of the goals set by the Malaysian Education Blueprint (2013-2025), that is to be above-global average and to be in the top one-third of countries in the international education standards by 2025, STEM education is one of the initiatives introduced by the Malaysian Ministry of Education. According to Rhoads (2004), the increasing flow in the STEM education pipeline is a good way in motivating children to further their interest in science and mathematics. Through STEM education, students are able to seek answers to real-life issues and explore global problems.

Moomaw states (2013) states that, "after decades of intense focus on developing literacy skills in earlychildhood programs, today the attention is shifting to the significance of teaching mathematics, technology, and science in the early years". Many developed countries like America, Australia, and Canada have started introducing STEM in their early childhood education system. In the Malaysia Education Blueprint (20132025), the initiatives to strengthen STEM across the education system are divided into three phases. The first phase, Wave I (2013-2015), focuses on strengthening the foundation of existing programmes and encouraging 
school students to enrol in the science stream. The second wave, Wave II (2016-2020), emphasises the construction of the foundation by engaging the support of a broader group of stakeholders. The third phase, Wave III (2021 - 2025), evaluates the successes of the two earlier waves so as to develop roadmaps for further innovations. Bybee (2010) says "STEM education is an approach that aims to teach these disciplines as an integrated whole, and it covers the whole process from early childhood to higher education". However, all the initiatives taken to strengthen STEM education are limited to the primary, secondary, and tertiary levels. There is no emphasis or guidelines in implementing STEM education for early childhood education even though, as reported by the Malaysian Department of Statistics, there has been an increase of $1.2 \%$ in the number of preschool students in government and government-aided schools.

A report by the Boston Children's Museum (2013) affirms that, the sooner students engage in real-world applications of science, technology, engineering, and mathematics, the better they will be in mastering the skills that come with each respective field. However, the lack of early exposure to STEM disciplines among younger children may lead to loss of interest and confidence in the STEM disciplines in the future. According to Sanders (2009), STEM education aims to improve students' imagination and develop solutions to challenges by ways of applying their mathematical and scientific knowledge in technological design, problem-based learning, and authentic scientific inquiry. Therefore, compared to the rigid traditional formal education in early childhood education, STEM education offers younger students the resources and opportunities to explore, investigate, and develop their own knowledge as active learners. Kumtepe and Genc-Kumtepe (2015) report, that until 2013, early childhood education was not included in STEM education's strategic plans. Soylu (2016) claims that countries like United Kingdom, Germany, Ireland and Finland have acknowledged STEM education as a priority in their education system. However, a further look into their education programs reveals that early childhood education still receives minor concern in these countries. Early childhood education has been neglected compared to primary and secondary educations for both funding and research in the STEM education plan. Therefore, there is a lack of studies on how to implement STEM education in early childhood education.

Coople and Bredekamp (2009) reported that, in order to promote children's learning within and across STEM disciplines, teachers need to give an appropriate attention to these disciplines while planning the curriculum. Therefore, to support this intervention of STEM education, it is necessary to develop a suitable curriculum. Soylu (2016) suggested several ways to implement STEM education in early childhood education which include hands-on experience and active involvement such as project-based learning and play-based learning. Furthermore, Chalufour (2010) claims that teachers in early childhood education need to develop their content knowledge in STEM fields and to learn how to implement STEM fields in the classroom with an integrated and developmentally appropriate approach. This is because teachers play a crucial role in ensuring the effectiveness of STEM learning in early childhood education. Regardless of the approaches used, effort has to be taken to develop a suitable curriculum for the integration of STEM education, Ong et al. (2016) has shown the feasibility of STEM integration for early childhood education. This is based on two facts - the existence of Science and Mathematics subjects in the existing curriculum, and the use of Project-Based Inquiry Learning in STEM education which matches the inquisitive nature of children.

\section{RESEARCH OBJECTIVE}

The general objective of this study is to infuse STEM in the mathematics curriculum framework of the existing preschool children's curriculum. The specific objectives are as follows:

i. To develop a mathematics curriculum framework for early childhood education based on STEM specifically for three- to four-year old children.

ii. To develop activities that can demonstrate the mathematics curriculum framework for early childhood education based on STEM specifically for three- to four-year old children.

iii. To explore teachers' or experts' perspectives on the mathematics curriculum framework and activities for early childhood education based on STEM specifically for three- to four-year old children.

\section{CONCEPTUAL FRAMEWORK}

This research draws on three main theories, which are early childhood development and curriculum theories, Science, Technology, Engineering and Mathematics (STEM) education, and the existing curriculum in developing the mathematics curriculum framework for early childhood education based on STEM 


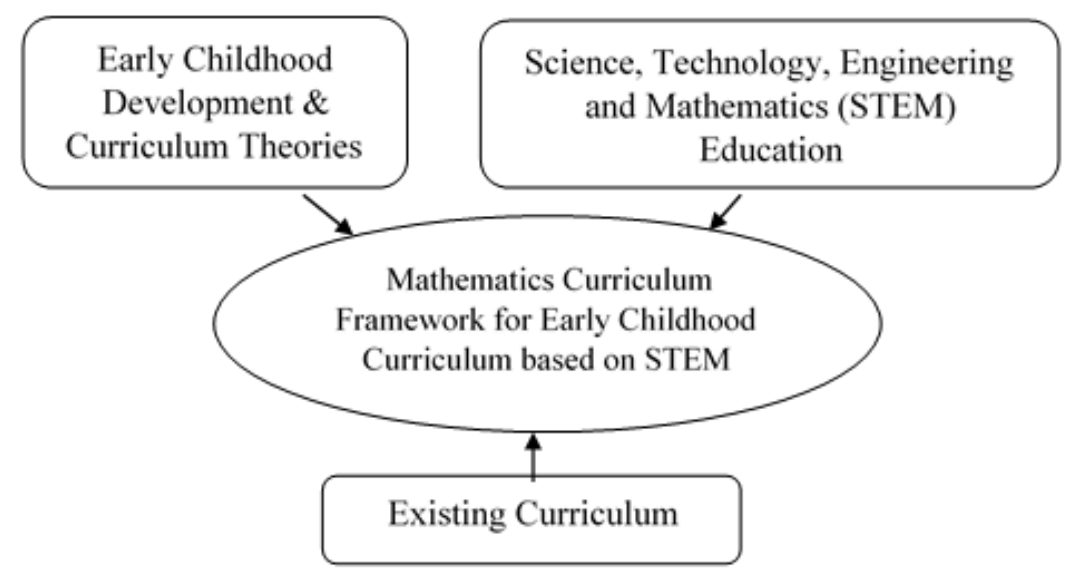

Figure 1. Conceptual framework of the study

specifically for children aged between three to four years old. Curriculum development theories play a crucial role in guiding the researcher in planning the framework. From these theories, appropriate activities and learning objectives that suit the student's needs and age can be derived. In addition, prior research on STEM education is a critical foundation that will provide suggestions on how to implement STEM in early childhood education in Malaysia. Figure 1 shows the conceptual framework of this study.

Early childhood development theories are important in supporting the framework developed in this study. Many researchers have shared their reactions on the early childhood development. For example, Vygotsky (1978) states that "human learning presupposes a specific social nature and a process by which children grow into the intellectual life of those around them". Ralph Tyler, one of the best-known curriculum theorists and reformers, highlights four basic principles of curriculum - educational purposes, educational experiences provided to fulfil the purposes, effective organisation of the educational experiences, and the determination whether the purposes have been fulfilled. Besides, the researcher also refers to the early childhood curriculum theory as it suits the needs of younger students. By comparing the existing curriculum with other countries' curricula, it will help the researcher in finding the advantages and disadvantages of the existing curriculum and ways to improve it.

\section{METHODOLOGY}

The development of the mathematics curriculum framework and the activities in this study was based on the ADDIE model. There are five phases in the ADDIE model which involves Analysis, Design, Development, Implementation and Evaluation. Figure 2 shows the flow chart of the development process in this study. In the evaluation phase, the researcher obtained the feedback from the respondents regarding the developed products. This study involved eight respondents. Two of them were the experts while the remaining respondents were teachers. A set of evaluation forms consisting of marking rubrics were developed to guide the teachers and experts in giving their feedback on the developed mathematics curriculum framework and activities.The rubric followed the template of rubric by Stevens and Levi (2005). There were five sections in the evaluation form. The first section was on the demography of the teachers or experts. The second section showed the items for the mathematics curriculum framework based on STEM. The third section provided the learning standard of mathematics topics in the curriculum framework based on STEM. The fourth section showed the teacher's guide for the STEM activities proposed by this research. The fifth section contained openended questions on recommendations or constructive comments of the developed product. In sections two to four in the evaluation form, nine criteria were listed for asssessment by the researcher. Each ctiteria was then divided into two items. Based on the products, the respondent provided marks (points) ranging from one to five, following the criteria and item in the evaluation form. Each point represented a statement regarding the products. The data obtained was then analysed using descriptive statistics. 


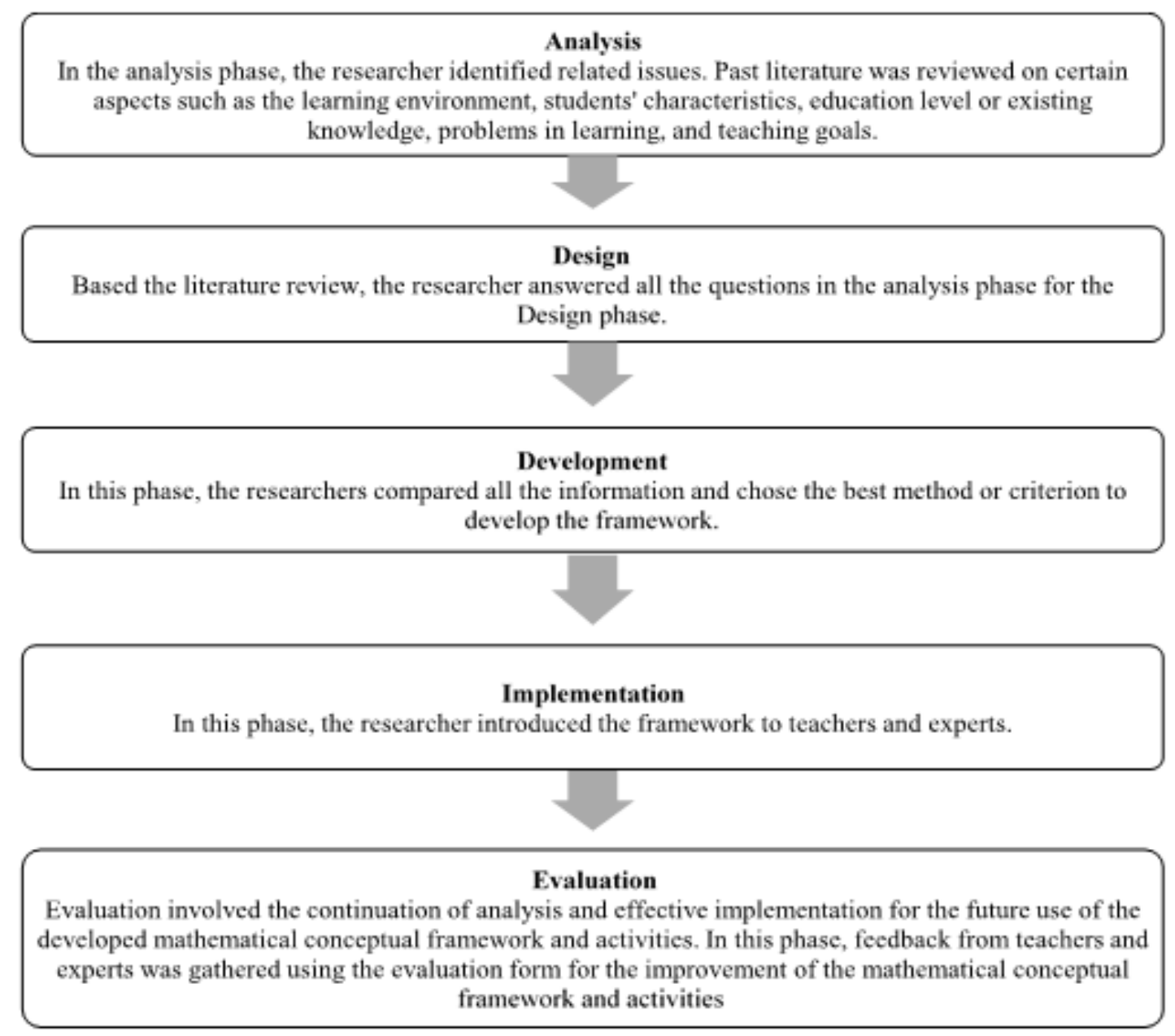

Figure 2. Flow Chart of the Development Process

\section{FINDINGS}

\section{Analysis}

The analysis phase was the foundation phase for the design of instructional strategies or programs. The analysis phase involved the process of identifying problems and solutions. The purpose of this process was to ensure the design of the mathematics curriculum framework would meet the needs of the respective teachers and students. In the context of the development of the mathematics curriculum framework and activities, the process of analysis involved three main aspects. Based on the three main aspects, several questions were then developed and answered through the analysis of past literature. The three main aspects were the analysis of children, the analysis of the learning environment, and the analysis of the teaching goals.

\section{Analysis of Children}

\section{What are the children's levels of knowledge in mathematics?}

According to Piaget's cognitive development theory, the children between two to seven years old have several characteristics. The characteristics are increasing in language ability, symbolic thought, egocentric perspective and limited logic. At this level, the children started to make rational thought, understand numbers and their operations. However, the children may have a hard time for reverse operations. For example, the children may understand 2 plus 5 is equal to seven, but they cannot perform the reverse operation of taking 5 from 7 is 2 . At this level, children's perceptions are generally restricted to one aspect or dimension. This statement is derived through an experiment in which Piaget tests the concept of conversation by pouring the same amount of liquid into two different containers. As the level is lower in the wider container, the children 
think there is less amount of liquid in that particular container. This shows the children at this level of age use one dimension, which is height, as the basis for his or her decision making. Hence, appropriate ways have to be taken in promoting children's cognitive development.

\section{What are the appropriate mathematics topics for the children?}

There are two main curricula for early childhood education in Malaysia, which are Kurikulum Permata and the Kurikulum Standard Prasekolah Kebangsaan (KSPK). After comparing the two curricula, the researcher found that the Kurikulum Permata was designed for children from their infancy to four years old, whereas KSPK focused for children from four to six years old. In order to ensure the continuation of topics to be learned in preschool, the researchers decided to follow KSPK which contained six main topics: Pre-Number Experience, Number Concept, Number Operation, Value of Money, Time Concept and Shape and Space.

\section{What is the importance of early mathematics for the children?}

By introducing early mathematics in early childhood education, children can acquire basic mathematics concepts to use in daily life and enhance their thinking and problem-solving skills. This is supported by Slavin (2014) who states that early mathematics is a core component of cognition which later predicts future mathematics and reading skills. Other than that, past research has shown that early mathematics helps children in developing their thinking skills logically, strategically, creatively and critically. Thus, more attention should be given to early mathematics topics in developing numeracy skills for younger children.

\section{Analysis of the Learning Environment}

\section{What are the suitable approaches to attract children to learn early mathematics?}

After comparing several instructional models, the researcher chose the $5 \mathrm{E}$ instructional model as the suitable approach to attract children to learn mathematics. The 5E instructional model provides a planned sequence of instruction that places children at the centre of their learning experiences, encourages them to explore, constructs their own understanding of concepts, and relates those understandings to other concepts. The 5E instructional model involves five steps of instruction which are engage, explore, explain, extend, and evaluate. The five steps in the $5 \mathrm{E}$ instructional models are crucial to ensure the teaching and learning session can be run smoothly.

What are the suitable resources or tools that can be implemented in the lesson?

According to Ojose (2008), children from two to seven years old should be engaged with problem-solving tasks that incorporate varieties of available materials such as blocks, sand and water. By using variety of materials, children's critical and creative thinking can be nurtured.

\section{Analysis of Teaching Goals \\ What are the appropriate standard learning outcomes or goals for the children?}

By comparing KSPK with several mathematics curricula in early childhood education in other countries such as United Kingdom and Singapore, the researcher developed the revised standard learning outcomes for the early mathematics subject (refer Table 2 for the suggested STEM activities to support the standard learning outcomes for the three- to four-year old children). The researchers followed the simple definition of STEM education in order to incorporate the STEM activities in the lesson.

\section{DESIGN}

In this phase, the researcher determined the goals to be achieved and carefully identified the important elements that should be inserted in the mathematics curriculum framework and activities. The goal of the development of the mathematics curriculum framework and activities was to guide teachers on how to implement the STEM approach in early childhood education. Based on the analysis phase, the researcher identified several important elements that should be inserted in the mathematics curriculum framework and activities. The elements comprised six topics that should be contained in the early childhood curriculum, the 5 E instructional models and Science, Technology, Engineering and Mathematics (STEM). Thus, the researcher designed the mathematics curriculum framework for early childhood education based on STEM specifically for three- to four-year old children as shown in Figure 3. 


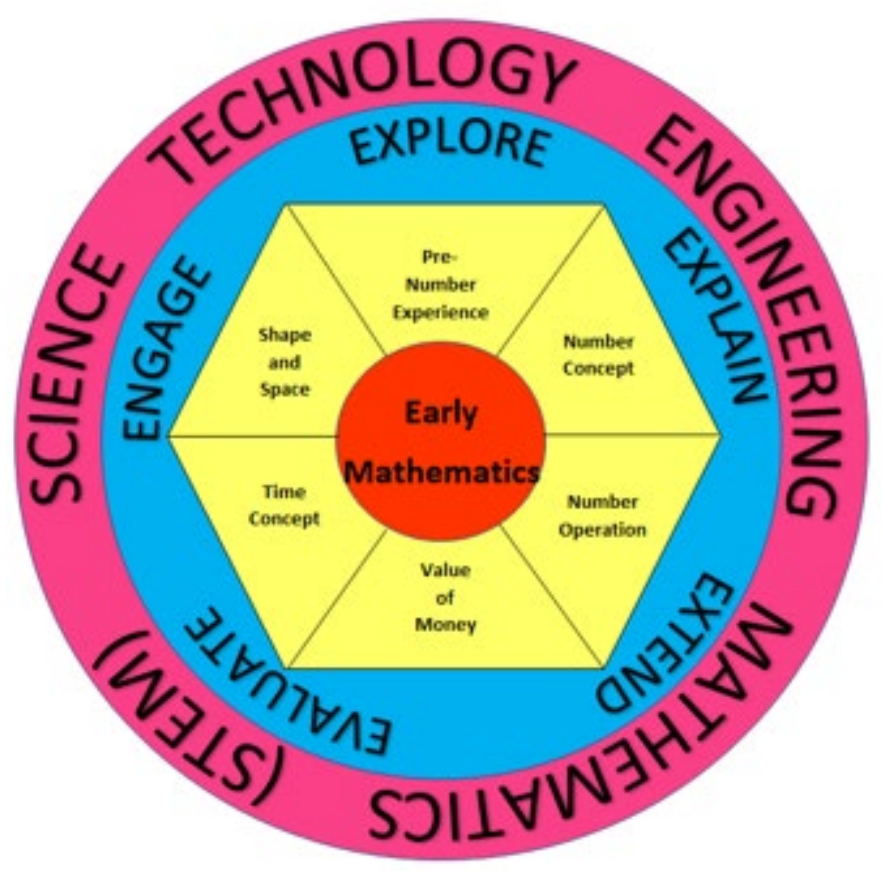

Figure 3. Mathematics curriculum framework for early childhood education (3-4 years old) based on Science, Technology, Engineering and Mathematics (STEM)

As shown in Figure 3. the mathematics curriculum framework for early childhood education (3-4 years old) based on STEM have six topics, as provided in the early mathematics in KSPK, which are Pre-number Experiences, Number Concepts, Number Operation, Value of Money, Time Concept, and Shape and Space. Following the mathematics curriculum framework, the lesson is conducted using the 5E instructional model which has five steps: Engage, Explore, Explain, Extend, and Evaluate. The 5E instructional model is emphasised in this mathematics curriculum framework to ensure the STEM activities can be conducted smoothly in class. The $5 \mathrm{E}$ instructional model can be adapted for any subject. It provides an easy guide for teachers to follow. Through each phase of learning, children have the chance to learn in a different way. The following is a description of each of these five steps:

i. Engage - The objectives of this first step of the $5 \mathrm{E}$ model are reaching students, getting their attention and guiding them to focus on a problem or a question. This step also stimulates their prior knowledge and helps relate what they have already learned to new concepts.

ii. Explore - In this phase of the 5E model, activities are introduced to provide students with materials and concepts in order to start to investigate the idea presented. They may discuss ideas with other students in groups and relate what they have already learned to this new idea. The teachers will know how much the students already know about the subject of the lesson.

iii. Explain - In this phase, teachers take an active role by introducing more detail in the form of terms, definitions and explanations for a specific subject or concept. Students begin to talk about their understanding and show the new skills they have learned.

iv. Extend - In this phase, teachers use activities that are challenging but can be achieved by the students. The students increase their understanding and begin to sharpen the skills through these learning experiences. They are encouraged to utilise what they have learned and apply it to a different but related concept.

v. Evaluate - This final phase is used to evaluate the final outcome. However, the 5E model is designed so that teachers can evaluate students' progress throughout the process by using formative assessment.

All the topics in the early mathematics will be integrated with STEM elements by incorporating STEM activities. According to Roberts (2016), every STEM activity should have at least two STEM elements in it. STEM is an educational program established to prepare the children to further their studies in the fields of 
Science, Technology, Engineering and Mathematics (STEM). In addition, STEM aims to cultivate inquiring minds, logical reasoning and collaboration skills needed in $21^{\text {st }}$ century learning. For this purpose, it is important to apply STEM elements in preschool teaching and learning.

\section{DEVELOPMENT}

From the mathematics curriculum framework, the researcher developed standard learning outcomes for the six topics in the framework. By comparing several mathematics curriculums in early childhood education in other countries such as United Kingdom and Singapore with the KSPK, the researcher developed the revised standard learning outcomes for the early mathematics subject. Based on the six main topics in the early mathematics that are Pre-number Experiences, Number Concepts, Number Operation, Value of Money, Time Concept, and Shape and Space, the researcher developed the standard learning outcomes accordingly. For example, the Pre-number Experience topic was divided into several sections of content standard namely:

i. Matching one to one is the association of similar or different objects. Examples of matching one to one for four-year old children are as follows:

a. Match identical pairs of things such as shoe-shoe, sock-sock.

b. Match non-identical pairs of things such as fork - spoon, shirt - pants.

c. Match two groups of objects that have equal quantity.

ii. Comparison is a process of associating two objects which uses specific characteristics as a basis for comparison. Examples of comparison are measurement (long - short), size (big - small), weight (heavy - light) and quantity (many - a few).

iii. Seriation is the arrangement of more than two objects according to succession based on clear criteria. For example, small to big, and short to long.

iv. Patterns are the way numbers or objects have been arranged according to a defined pattern.

v. Consistency is an aspect which can be connected to mass, volume and area. The concept of consistency is introduced to ensure that children will understand the concept of mass and volume even though they are placed or arranged in differing places or situations. For example, understand that spreading out or putting closely a group of objects does not affect its quantity and understand that shape of jar does not affect its amount.

Table 1 shows the example of the standard learning outcomes for the first topic of the early mathematics that is Pre-number Experience. From the table, it can be observed that the standard learning outcomes for the four-year old children is mainly the continuation of the standard learning outcomes of the three-year old children. However, there are several standard learning outcomes that are not appropriate for the three-year old children. So, the researcher decided that the content and standard learning outcomes would begin with four-year old children.

After the completion of the standard learning outcomes for each of the topics in the early mathematics, the researcher suggested suitable STEM activities for each content standard. Thus, a total of nineteen STEM activities were developed in which seven STEM activities were for three-year old children and twelve STEM activities were for four-year old children. The STEM activities involved the use of different kinds of materials and resources to support the learning need of the children. From the activities developed, the researcher emphasized the STEM element that should be focused during the activities. According to Roberts (2016), it is enough if the STEM activities integrate at least two STEM elements. 
Table 1. Example of the Standard Learning Outcomes for the First Topic of the Early Mathematics

\begin{tabular}{|c|c|c|c|}
\hline \multirow[t]{2}{*}{ Focus } & \multirow{2}{*}{$\begin{array}{l}\text { Content } \\
\text { Standard }\end{array}$} & \multicolumn{2}{|c|}{$\begin{array}{l}\text { Learning Standard } \\
\text { Children in the following age groups should be able to: }\end{array}$} \\
\hline & & $3+$ & $4+$ \\
\hline \multirow{5}{*}{$\begin{array}{l}\text { Pre-number } \\
\text { Experience }\end{array}$} & $\begin{array}{l}\text { Match objects } \\
1: 1\end{array}$ & $\begin{array}{l}\text { Discover designs and shapes in } \\
\text { environment. } \\
\text { Know identical and non- identical } \\
\text { things. }\end{array}$ & $\begin{array}{l}\text { Match identical pairs of things e.g. } \\
\text { shoe-shoe, sock-sock. } \\
\text { Match non-identical pairs of things, e.g. } \\
\text { shoe-sock, shirt-pants. } \\
\text { Match two groups of objects that have } \\
\text { equal quantity. }\end{array}$ \\
\hline & $\begin{array}{l}\text { Compare the } \\
\text { quantity of } \\
\text { objects }\end{array}$ & $\begin{array}{l}\text { Compare two different quantities of } \\
\text { object and state many or few. }\end{array}$ & $\begin{array}{l}\text { Compare two groups of objects by } \\
\text { stating: } \\
\text { (i) equal or not equal } \\
\text { (ii) more or less }\end{array}$ \\
\hline & $\begin{array}{l}\text { Make series } \\
\text { according to one } \\
\text { feature. }\end{array}$ & $\begin{array}{l}\text { Recognise objects based on: } \\
\begin{aligned} \text { a. } & \text { Small or Big } \\
\text { b. } & \text { Short or Long } \\
\text { c. } & \text { Low or High } \\
\text { d. } & \text { Thin or Thick }\end{aligned}\end{array}$ & $\begin{array}{l}\text { Arrange the object following the criteria } \\
\text { below: } \\
\text { a. Small to Big } \\
\text { b. Short to Long } \\
\text { c. Low to High } \\
\text { d. Thin to Thick }\end{array}$ \\
\hline & $\begin{array}{l}\text { Recognise the } \\
\text { repetition of } \\
\text { patterns and } \\
\text { build patterns. }\end{array}$ & & $\begin{array}{l}\text { Recognize and state patterns in the } \\
\text { environment } \\
\text { Copy patterns }\end{array}$ \\
\hline & $\begin{array}{l}\text { Understand the } \\
\text { concept of } \\
\text { consistency. }\end{array}$ & & $\begin{array}{l}\text { Understand that spreading out or } \\
\text { putting closely a group of objects does } \\
\text { not affect its quantity. } \\
\text { Understand that shape of jar does not } \\
\text { affect its amount. }\end{array}$ \\
\hline
\end{tabular}

Table 2 shows an example of STEM activities for the first content standard in the Pre-number Experience topic, which is match object one to one. From Table 2, the activity suggested to achieve the standard learning outcomes for the three-year old children is outdoor discovery. In this activity, the teacher will have outdoor walks with the children and ask them to collect, match and sort everyday objects to identical and non-identical pairs from nature. Outdoor discovery activities help children discover designs and shapes of objects and help them recognize identical and non-identical things in the environment. From the outdoor discovery activity, the researcher identified three elements of STEM, which are science in which the children discover designs and shapes in nature, technology in which the children learn to use magnifying glass, and mathematics in which the children learn to match and sort things. Then, the researcher suggested the resources and tools that needed for the activity, the worksheet to evaluate the learning of the student, and the recommendation of material that the teacher could use to support the activity. 
Table 2. An Example of STEM Activities for the Matching Objects (one to one) in the Pre-Number Experience Topics in Early Mathematics

\begin{tabular}{|c|c|c|c|}
\hline \multirow[t]{2}{*}{ Focus } & \multirow{2}{*}{$\begin{array}{l}\text { Content } \\
\text { Standard }\end{array}$} & \multicolumn{2}{|l|}{ STEM Activities } \\
\hline & & $3+$ & $4+$ \\
\hline Pre-number & Match & Outdoor Discovery & Mystery Box \\
\hline Experience & objects $1: 1$ & $\begin{array}{l}\text { Go on outdoor walks with the } \\
\text { children and ask them to collect, } \\
\text { match and sort everyday objects to } \\
\text { identical pairs from nature and let } \\
\text { the children explore using } \\
\text { magnifying glass. } \\
\text { S - Discover designs and shapes in } \\
\text { nature. } \\
\text { T - Learn to use magnifying glass. } \\
\text { M- Match and sort things. } \\
\text { Resources \& tools: } \\
\text { - Magnifying glass. } \\
\text { Worksheet: } \\
\text { - Worksheet for matching several } \\
\text { objects based on criteria using a } \\
\text { sticker. } \\
\text { - Colouring a book. } \\
\text { Recommendation: } \\
\text { - Sticker/ picture story book in } \\
\text { which children can paste the } \\
\text { identical pairs. }\end{array}$ & $\begin{array}{l}\text { Children randomly pick an object from the } \\
\text { mysterious box and find a partner who has } \\
\text { the identical object to match with the object } \\
\text { that they get. Repeat the instruction for non- } \\
\text { identical objects. } \\
\text { S - Observe what the objects that their peers } \\
\text { have. } \\
\mathbf{T} \text {-Using the object that they have to find } \\
\text { their partner. } \\
\text { E- Create a pair of identical and non- } \\
\text { identical objects. } \\
\text { M- Pairing objects. } \\
\text { Resources \& tools: } \\
\text { - Mysterious box with variety of pairs of } \\
\text { objects in it. } \\
\text { - Flashcard for identical and non-identical } \\
\text { objects. } \\
\text { Worksheet: } \\
\text { - Maths Book \& Activity Book 1- Unit } 1 \text {, } \\
\text { Page 2-3 \& } 16 \text {. } \\
\text { Recommendation: } \\
\text { - Worksheet: children draw the pairs of the } \\
\text { given picture. }\end{array}$ \\
\hline
\end{tabular}

From the suggested STEM activities, the researcher carefully planned the lesson to guide the teachers to conduct STEM activities according to the 5E instructional model in the classroom. High-quality STEM experiences may provide engagement, confidence, curiosity, and understanding of the younger children towards the integrated STEM disciplines. In addition, incorporating the 5E Instructional Model in the STEM approach provides positive experiences, which helps children develop dispositions such as curiosity, imagination, flexibility, inventiveness, and persistence. These traits will contribute to their future success beyond the school environment. Thus, the lesson plans provided in this teacher's guide are based on using STEM as an approach to teach basic mathematics concepts to younger children through the application of the 5E Instructional Model. This teacher's guide includes proposed activities that give teachers a sense of idea to integrate STEM in their teaching and learning for younger children using the 5E Instructional Model. For the lesson plan, the researcher prepared only one for every topic following the suggested STEM activities and standard learning outcomes. Figure 4 shows the example of lesson plan for the STEM activity to achieve the standard learning outcomes for the three-year old children. 


\begin{tabular}{|c|c|c|}
\hline \multicolumn{3}{|c|}{ Lesson plan 1: Activity - Outdoor Discovery for the three-year old children } \\
\hline \multicolumn{3}{|c|}{$\begin{array}{c}\text { i. } \begin{array}{c}\text { Discover designs and shapes in environment. } \\
\text { Introduction to identical and non-identical shapes. }\end{array} \\
\text { Instruction: Go outdoor walks with the children and ask the children to collect, match and sort everyday things from } \\
\text { nature and let the children explore using a magnifying glass. } \\
\text { Tools needed: Magnifying glass, related video, songs, flashcard and colouring worksheet. } \\
\text { Location: Outdoor environment in the kindergarten area. } \\
\text { The } 5 \mathrm{E} \text { instructional model }\end{array}$} \\
\hline Phase & Instruction & Notes \\
\hline Engage & $\begin{array}{l}\text { 1. Children listen, sing and dance to shape songs. } \\
\text { 2. Children watch a video or listen to a story told by the teacher } \\
\text { related to things in a real life with identical and non-identical shapes } \\
\text { in the environment. }\end{array}$ & \multirow{5}{*}{$\begin{array}{c}\text { S - Discover designs and } \\
\text { shapes in nature } \\
\text { T - Learn to use a } \\
\text { magnifying glass. } \\
\text { M- Match identical and non- } \\
\text { identical shapes }\end{array}$} \\
\hline Explore & $\begin{array}{l}\text { 1. Children go outside of classroom guided by the teacher and collect } \\
\text { things that interest them the most. } \\
\text { 2. Children use a magnifying glass to explore. }\end{array}$ & \\
\hline Explain & $\begin{array}{l}\text { 1. Children explain, show or illustrate what they observe and collect } \\
\text { from the environment. } \\
\text { 2. Children explain on why they choose a particular object or thing. }\end{array}$ & \\
\hline Extend & $\begin{array}{l}\text { 1. All the things collected are gathered. Then, children in groups are } \\
\text { asked to match and sort the things to identical and non-identical } \\
\text { shapes. }\end{array}$ & \\
\hline Evaluate & $\begin{array}{l}\text { 1. Children match the identical and non-identical shapes using } \\
\text { flashcards. } \\
\text { 2. Children are given sticker/ picture worksheets in which they can } \\
\text { match and categorize the stickers in the space provided. }\end{array}$ & \\
\hline \multicolumn{3}{|c|}{$\begin{array}{l}\text { Recommendation: } \\
\text { identical and non-identical shapes in the environment } \\
\text { ch and categorize the objects in the picture and stick them in the space } \\
\text { provided. }\end{array}$} \\
\hline
\end{tabular}

Figure 4. An example of a lesson plan for the STEM activity to achieve the standard learning outcomes

\section{IMPLEMENTATION AND EVALUATION}

The implementation phase was the phase in which the researcher introduced the mathematics curriculum framework and activities to the teachers and experts. In order to ensure that the product was delivered effectively, the researcher had to get the feedback from the teachers and experts. The researcher met up with two experts. One of them was an expert in STEM education and another one was an expert in early childhood education. Other than that, the researcher also met up with six teachers in early childhood education in order to introduce the mathematics curriculum framework and activities for the three to four-year old children. The researcher compiled the mathematics curriculum framework based on STEM, the standard learning outcomes, the suggested STEM activities to achieve the learning outcomes, and the teacher's guide in a document to make it easy for the teachers and experts to understand. Before introducing the mathematics curriculum framework and activities, the researcher first explained the need of incorporating STEM education in early childhood education. Then, the researchers explained the benefit of using the $5 \mathrm{E}$ instructional model in the lesson. Finally, the researcher explained the development and key elements of the mathematics curriculum framework and activities.

In this phase, the researcher distributed the evaluation form to the respondents. There were five sections in the evaluation form. The first section contained the demographic details of the respondents, the second section showed the evaluation for the mathematics curriculum framework based on STEM, the third section listed the standard learning outcomes of the mathematics topics, the fourth section displayed the lesson plan (teacher's guide) for the STEM activities, and the last section provided the recommendation. The rubric followed the template by Stevens and Levi (2005). For each section, there were nine criteria to be assessed by the researcher. The criteria were presentation, content, language, suitability and overall impression. Each of the criteria was divided into two items. The respondents gave marks (points) ranging from one to five following the criteria and items in the evaluation form. Each point represented a statement regarding the products. There was also space for the respondent to give comments and recommendations regarding the products. 
Table 3. Analysis of the Respondent's Evaluation of the Mathematics Curriculum Framework Based on STEM

\begin{tabular}{|c|c|c|c|c|c|c|c|}
\hline Criteria & Item & 5 & 4 & 3 & 2 & 1 & Median \\
\hline \multirow{2}{*}{ Presentation } & Layout & & $\begin{array}{c}6 \\
(75.00 \%)\end{array}$ & $\begin{array}{c}2 \\
(25.00 \%)\end{array}$ & & & 4 \\
\hline & Arrangement & & $\begin{array}{c}7 \\
(87.50 \%) \\
\end{array}$ & $\begin{array}{c}1 \\
(12.50 \%)\end{array}$ & & & 4 \\
\hline \multirow{2}{*}{ Content } & Meaning & & $\begin{array}{c}5 \\
(62.50 \%) \\
\end{array}$ & $\begin{array}{c}2 \\
(25.00 \%) \\
\end{array}$ & $\begin{array}{c}1 \\
(12.50 \%)\end{array}$ & & 4 \\
\hline & Information & & $\begin{array}{c}5 \\
(62.50 \%)\end{array}$ & $\begin{array}{c}3 \\
(37.50 \%) \\
\end{array}$ & & & 4 \\
\hline \multirow{2}{*}{ Language } & Clear and Convincing & $\begin{array}{c}1 \\
(12.50 \%)\end{array}$ & $\begin{array}{c}5 \\
(62.50 \%) \\
\end{array}$ & & $\begin{array}{c}2 \\
(25.00 \%) \\
\end{array}$ & & 4 \\
\hline & $\begin{array}{l}\text { Grammatical and } \\
\text { understandable }\end{array}$ & $\begin{array}{c}1 \\
(12.50) \\
\end{array}$ & $\begin{array}{c}5 \\
(62.50 \%) \\
\end{array}$ & $\begin{array}{c}1 \\
(12.50 \%) \\
\end{array}$ & $\begin{array}{c}1 \\
(12.50 \%) \\
\end{array}$ & & 4 \\
\hline \multirow{2}{*}{ Suitability } & Formal learning & & $\begin{array}{c}2 \\
(25.00 \%) \\
\end{array}$ & $\begin{array}{c}4 \\
(50.00 \%) \\
\end{array}$ & $\begin{array}{c}1 \\
(12.50 \%) \\
\end{array}$ & $\begin{array}{c}1 \\
(12.50 \%)\end{array}$ & 3 \\
\hline & Informal learning & & $\begin{array}{c}4 \\
(50.00 \%) \\
\end{array}$ & $\begin{array}{c}3 \\
(37.50 \%) \\
\end{array}$ & & $\begin{array}{c}1 \\
(12.50 \%) \\
\end{array}$ & 3.5 \\
\hline Overall & Impression & & $\begin{array}{c}4 \\
(50.00 \%)\end{array}$ & $\begin{array}{c}4 \\
(50.00 \%)\end{array}$ & & & 4 \\
\hline
\end{tabular}

\section{Analysis of Respondent's Evaluation of the Mathematics Curriculum Framework for Early Childhood Education based on STEM}

The second section in the evaluation form aimed to examine the teacher's feedback regarding the developed mathematics curriculum framework for early childhood education based on STEM. The findings from the second section are represented in percentage and median values. Table 3 shows the analysis of respondent's evaluation of the mathematics curriculum framework based on STEM specifically for three to four-year old children.

Based on Table 3, 75\% of the respondents gave 4 points to the layout criteria. That is, the layout had a good design and an overview of the content. For the arrangement of the mathematics curriculum framework, most of the respondents agreed that the mathematics curriculum framework had a good arrangement. For the content criteria, $62.50 \%$ of the respondents gave 4 points for both meaning and information items. That is, most of respondents thought agreed the content was suitable for the children's abilities, needs and interests, and the framework provided clear information of the content. For the language criteria, $62.50 \%$ of the respondents agreed that the words used were clear and convincing. For the suitability criteria, most of the respondents decided that the mathematics curriculum framework was more suitable for informal learning than formal learning. $50.00 \%$ of the respondents agreed that the overall impression of the respondents on the mathematics curriculum framework was good. Half of them agreed that the overall impression was moderate. The median for all the criteria was 4, indicating that the respondents gave positive feedback regarding the mathematics curriculum framework based on STEM specifically for three- to four-year old children.

\section{Analysis of Respondent's Evaluation of the Standard Learning Outcomes of the Mathematics Topics in the Mathematics Curriculum Framework based on STEM}

Table 4 shows the analysis of respondent's evaluation of the standard learning outcomes of the mathematics topics in the curriculum framework based on STEM specifically for three- to four-year old children. The data is presented in percentage and median values. 
Table 4. Analysis of the respondent's evaluation of the standard learning outcomes of the mathematics topics in the curriculum framework based on STEM

\begin{tabular}{|c|c|c|c|c|c|c|c|}
\hline Criteria & Item & 5 & 4 & 3 & 2 & 1 & Median \\
\hline \multirow{2}{*}{ Presentation } & Layout & $\begin{array}{c}1 \\
(12.50 \%)\end{array}$ & $\begin{array}{c}5 \\
(62.50 \%)\end{array}$ & $\begin{array}{c}1 \\
(12.50 \%)\end{array}$ & $\begin{array}{c}1 \\
(12.50 \%)\end{array}$ & & 4 \\
\hline & Arrangement & & $\begin{array}{c}4 \\
(50.00 \%)\end{array}$ & $\begin{array}{c}3 \\
(37.50 \%)\end{array}$ & $\begin{array}{c}1 \\
(12.50 \%)\end{array}$ & & 3.5 \\
\hline \multirow{2}{*}{ Content } & Meaning & & $\begin{array}{c}3 \\
(37.50 \%)\end{array}$ & $\begin{array}{c}4 \\
(50.00 \%)\end{array}$ & $\begin{array}{c}1 \\
(12.50 \%)\end{array}$ & & 3 \\
\hline & Information & & $\begin{array}{c}3 \\
(37.50 \%) \\
\end{array}$ & $\begin{array}{c}5 \\
(62.50 \%) \\
\end{array}$ & & & 3 \\
\hline \multirow{2}{*}{ Language } & Clear and Convincing & & $\begin{array}{c}6 \\
(75.00 \%)\end{array}$ & $\begin{array}{c}1 \\
(12.50 \%)\end{array}$ & $\begin{array}{c}1 \\
(12.50 \%)\end{array}$ & & 4 \\
\hline & $\begin{array}{l}\text { Grammatical and } \\
\text { understandable }\end{array}$ & $\begin{array}{c}1 \\
(12.50 \%)\end{array}$ & $\begin{array}{c}4 \\
(50.00 \%)\end{array}$ & $\begin{array}{c}2 \\
(25.00 \%)\end{array}$ & $\begin{array}{c}1 \\
(12.50 \%)\end{array}$ & & 4 \\
\hline \multirow{2}{*}{ Suitability } & Formal learning & & $\begin{array}{c}3 \\
(37.50 \%)\end{array}$ & $\begin{array}{c}4 \\
(50.00 \%)\end{array}$ & & $\begin{array}{c}1 \\
(12.50 \%)\end{array}$ & 3 \\
\hline & Informal learning & & $\begin{array}{c}4 \\
(50.00 \%)\end{array}$ & $\begin{array}{c}3 \\
(37.50 \%)\end{array}$ & $\begin{array}{c}1 \\
(12.50 \%)\end{array}$ & & 3.5 \\
\hline Overall & Impression & & $\begin{array}{c}5 \\
(62.50 \%)\end{array}$ & $\begin{array}{c}3 \\
(37.50 \%)\end{array}$ & & & 4 \\
\hline
\end{tabular}

As seen in Table 4 for the presentation criteria, $62.50 \%$ and $50.00 \%$ of the respondents gave 4 points for the layout and arrangement item, respectively, indicating that most of the respondents agreed that the use of table gave a good overview of the standard learning outcomes and the standard learning outcomes had a good arrangement. Next, the same number of respondents (37.50\%) gave 3 and 4 points to the meaning criteria in the content criteria. Most of the respondents gave 4 points to the information criteria, showing that most of the respondents agreed that the standard learning outcomes had enough information. For the language criteria, most of the respondents gave 4 points for the clear and convincing item and the grammatical and understandable item. Comparing the formal learning and informal learning score, more respondents thought that the standard learning outcomes were suitable for informal learning than formal learning. $62.50 \%$ of the respondents gave 4 points for the overall impression, indicating that the overall impression for the standard learning outcomes was good. The median of all nine items was 3.5, showing that the respondents provided positive feedback regarding the standard learning outcomes of the mathematics topics in the curriculum framework based on STEM specifically for three- to four-year old children.

\section{Analysis of Respondent's Evaluation of the Lesson Plan for the STEM Activities}

Table 5 shows the analysis of respondent's evaluation of the lesson plan for the STEM activities specifically for three- to four-year old children. The data is presented in percentage and median values.

As seen in Table 5, 50.00\% and 62.50\% of the respondents gave 4 points for the layout and arrangement item, respectively. Most of the respondents agreed that the lesson plan showed a good overview of the content and the lesson plan had a good arrangement. The activities were also appropriate. For the content criteria, $62.50 \%$ of the respondents thought that the content was clear and suitable for the children. For the meaning criteria, $37.50 \%$ of the respondents gave 3 points, showing that the lesson plan had enough information for the activities. However, 2 points were given to the lesson plan, indicating the lesson plan did not have not enough explanation for the activities. For the language criteria, $62.50 \%$ of the respondents gave 4 points for the clear and convincing item, and $50.00 \%$ of the respondents gave 3 points for the grammatical and understandable item. Most of the respondents agreed that the words used were clear and convincing, and the words used were also good and understandable. For the suitability criteria, $12.50 \%$ of the respondents gave full points to the formal learning and informal learning items. The remaining respondent gave 1, 3 and 4 points for the suitability item in informal and formal learning. Half of the respondents (50.00\%) agreed that the overall impression for the lesson plan was good. The median of all nine items was 4 , showing that the respondents gave positive feedback regarding the lesson plan for the STEM activities specifically for three- to four-year old children. 
Table 5. Analysis of the respondent's evaluation for the lesson plan

\begin{tabular}{|c|c|c|c|c|c|c|c|}
\hline Criteria & Item & 5 & 4 & 3 & 2 & 1 & Median \\
\hline \multirow{2}{*}{ Presentation } & Layout & & $\begin{array}{c}4 \\
(50.00 \%)\end{array}$ & $\begin{array}{c}4 \\
(50.00 \%)\end{array}$ & & & 4 \\
\hline & Arrangement & & $\begin{array}{c}5 \\
(62.50 \%) \\
\end{array}$ & $\begin{array}{c}3 \\
(37.50 \%) \\
\end{array}$ & & & 4 \\
\hline \multirow{2}{*}{ Content } & Meaning & & $\begin{array}{c}2 \\
(25.00 \%) \\
\end{array}$ & $\begin{array}{c}5 \\
(62.50 \%) \\
\end{array}$ & & $\begin{array}{c}1 \\
(12.50 \%)\end{array}$ & 3 \\
\hline & Information & & $\begin{array}{c}2 \\
(25.00 \%)\end{array}$ & $\begin{array}{c}3 \\
(37.50 \%) \\
\end{array}$ & $\begin{array}{c}3 \\
(37.50 \%) \\
\end{array}$ & & 3 \\
\hline \multirow{2}{*}{ Language } & Clear and Convincing & & $\begin{array}{c}5 \\
(62.50 \%) \\
\end{array}$ & $\begin{array}{c}3 \\
(37.50 \%) \\
\end{array}$ & & & 4 \\
\hline & $\begin{array}{l}\text { Grammatical and } \\
\text { understandable }\end{array}$ & & $\begin{array}{c}4 \\
(50.00 \%) \\
\end{array}$ & $\begin{array}{c}4 \\
(50.00 \%) \\
\end{array}$ & & & 4 \\
\hline \multirow{2}{*}{ Suitability } & Formal learning & $\begin{array}{c}1 \\
(12.50 \%) \\
\end{array}$ & $\begin{array}{c}5 \\
(62.50 \%) \\
\end{array}$ & $\begin{array}{c}1 \\
(12.50 \%) \\
\end{array}$ & & $\begin{array}{c}1 \\
(12.50 \%) \\
\end{array}$ & 4 \\
\hline & Informal learning & $\begin{array}{c}1 \\
(12.50 \%) \\
\end{array}$ & $\begin{array}{c}3 \\
(37.50 \%) \\
\end{array}$ & $\begin{array}{c}3 \\
(37.50 \%) \\
\end{array}$ & & $\begin{array}{c}1 \\
(12.50 \% \\
\end{array}$ & 3.5 \\
\hline Overall & Impression & & $\begin{array}{c}4 \\
(50.00 \%)\end{array}$ & $\begin{array}{c}4 \\
(50.00 \%)\end{array}$ & & & 4 \\
\hline
\end{tabular}

\section{DISCUSSION}

The developed mathematics curriculum framework included three main elements, which were the six main topics in the early mathematics, the 5E instructional model, and Science, Technology, Enginnering and Mathematics (STEM). The six topics in the mathematics curriculum framework followed the early mathematics in KSPK, which were Pre-number Experiences, Number Concepts, Number Operation, Value of Money, Time Concept, and Shape and Space. Early Childhood Education Division (PERMATA) (2013) stated that three- to four-year old children were ready to be equipped with early mathematics knowledge and skills consisting of concepts such as quantity, budget, equation, difference, comparison, welding and sorting (sorting), initial number and number representation, one-to-one match, sequence (series), shape, pattern, space, time, position, measure, size, number, count and number operation. Compared to the KSPK, several mathematics skills were introduced in this developed standard learning outcome for the framework such as subtizing and the part-whole relationship. This was adapted from the Curriculum for Kindergartens in Singapore by the Ministry of Education Republic of Singapore (2013). The part-whole relationship is an understanding that a number can be composed of smaller parts. Children should understand that five blocks can be made up of two blocks and one block or one block and four blocks. When children are able to interpret a quantity in terms of its parts, it lays the foundation for understanding operations such as addition and subtraction. Next, subitizing is an important skill that relates to the development of children's number sense. It refers to the ability to recognise the number of objects in a set without actually counting each individual object. Children who can identify small quantities in different arrangements, such as those on dominoes or dice, without actually counting them one by one, means that they have a strong sense of quantity.

The 5E instructional design (engage, explore, explain, extend and evaluate) was emphasised in this study. This is because, according to Yoon and Onchwari (2006), the 5E instructional model provides teachers an opportunity that can lead children to exercise their innate curiousity, learn about the natural world and develop problem-solving skills. According to Campbell (2006), in the first phase, engage, students' prior knowledge of a concept is elicited and connections to present and future topics are encouraged to attract students' interest in the topics. Then, during the explore stage, students carry out the activity or the experiment by collecting data, making observations. These explorations will lead to the explain stage. In the extend stage, students have the opportunity to extend their learning to other topics. In the evaluate stage, both teachers and students will have the chance to both formally and informally reflect upon what has been learned.

In the developed mathematics curriculum framework, the STEM element enclosed all the other elements, indicating that that the STEM element was applicable across the other elements. A report by Moomaw and Davis (2010) shows that the STEM-based curriculum helps children focus, increase their vocabulary, 
collaborate with one another and create scientific relationships. Furthermore, the Early Childhood STEM Working Group (2017) states children from different socioeconomic circumstances enter kindergarten with large differences in math and science knowledge and that these differences tend to persist or even grow over time. However, the gaps in mathematics and science knowledge can be reduced by introducing STEM in early childhood education. To support the feasibility of STEM in early childhood education, Ong et al. (2016) indicate that it is feasible to integrate STEM into early childhood education.

From the developed mathematics curriculum framework, the researcher developed STEM activities and lesson plans to conduct the activities as the guideline for the teachers. Based on the findings, for the suitability criteria for the STEM activities, $12.50 \%$ of the respondents gave full points to the formal learning and informal learning items. The other respondents gave 3 and 4 points for suitability in the informal and formal learning items. However, a respondent gave a score of 1 for the suitability of the STEM activities. Adnan et al. (2016) state that the integration of STEM in early childhood education is feasible although some adults mistakenly think that STEM activities are too challenging to integrate into preschool settings. Furthermore, Moomaw and Davis (2010) report that the STEM activities allow children to explore materials using all their senses. While they experiment and investigate the materials, they develop an understanding of important mathematical relationships. The suggested STEM activities were developed with a strong idea of learning through play. According to Froebel, playing is a natural condition that helps children learn and grow. Through play, children can build their own knowledge by exploring and trying a new activity. Playing allow the children to meet their needs of curiosity, as well as enhance their knowledge, experience and skills. However, to achieve the standard learning outcomes, the types of play emphasised in this study was guided play. According Weisberg (2016), guided play refers to learning experiences that combine the child-directed nature of free play with a focus on learning outcomes and adult mentorship. In conducting the STEM activities in the classroom, the teacher may incorporate the guided play by following the $5 \mathrm{E}$ instructional model. As reported by Morrison (2007), one of the important criteria stated in the Montessori Curriculum that enables children to learn is a prepared environment. Children who are actively involved in a prepared environment and who exercise the freedom of choices literally self-educate themselves. The suggested STEM activities involved the use of different kinds of materials and resources to support the learning need of the children. In addition, in the lesson plan in this study, the researcher also emphasised tools, resources and other recommendation of materials that helped children to learn.

In the implementation phase, the researcher met up with two experts. One of the experts was an expert in STEM education and another one was an expert in early childhood education. Other than that, the researcher also met up with six teachers in early childhood education to introduce the developed mathematics curriculum framework and activities. The feedback of the teachers and experts were gathered through the evaluation form. All the respondents commented that the integration of STEM education in the early childhood education was a good attempt but it could be improved in the future. Similarly, Soylu (2016) reports that more effort is necessary in developing age-appropriate instruction tools to promote STEM in early childhood settings. The median for the whole developed products was 4 points. Overall, the respondents gave positive feedbacks for the developed mathematics curriculum framework, standard learning outcomes, STEM activities and lesson plans in this study. However, some respondents commented that KSPK might not be age-appropriate for the three-year old children. On the other hand, Adnan et al. (2016) show that the STEM education can be implemented in the Kurikulum PERMATA for the three- to four-year old children. Hence, for future improvement of the study, the researcher might have to refer to the Kurikulum PERMATA which is more appropriate to the age group of this study. In addition, for the lesson plan, a respondent suggested that, instead of focusing on what the children should do, the lesson plan should focus on what the teacher should do. All the comments and recommendation from the respondents were used for the improvement of the developed products.

\section{CONCLUSION}

Overall, the objectives of the study were achieved. The developed mathematics curriculum framework, standard learning outcomes, STEM activities and standard learning outcomes received positive feedback from the respondents. However, there were still some weaknesses in the products developed by this study. Hence, all the findings in this study will be used for future research. All the comments and recommendation from the respondents will be used for the improvement of the developed products. In addition, more efforts have to be taken by government, organisation, community and individual to promote STEM in early childhood education. 


\section{Disclosure statement}

No potential conflict of interest was reported by the authors.

\section{Notes on contributors}

Muhammad Nasiru Hassan - Sokoto State University, Nigeria.

Abdul Halim Abdullah - School of Education, Universiti Teknologi Malaysia (UTM)

Norulhuda Ismail - School of Education, Universiti Teknologi Malaysia (UTM)

Siti Norbazilah Ahmad Suhud - School of Education, Universiti Teknologi Malaysia (UTM)

Mohd Hilmi Hamzah - School of Languages, Civilisation and Philosophy, UUM College of Art and Science, Universiti Utara Malaysia

\section{REFERENCES}

Adnan, M., Ayob, A., Ong, E. T., Ibrahim, M. N., Ishak, N., \& Sheriff, J. (2016). Memperkasa pembangunan modal insan Malaysia diperingkat kanak-kanak: Kajian kebolehlaksanaan dan kebolehintegrasian pendidikan STEM dalam kurikulum PERMATA Negara. Geografia: Malaysian Journal of Society and Space, 12(1), 29-36.

Ali, A. T. (2012). Teaching and learning of science and mathematics in schools: towards a more creative and innovative Malaysia. Paper presented at the Colloquium Science and Mathematics Education, Universiti of Malaya, Kuala Lumpur.

Boston Children's Museum (2013). STEM sprouts: Science, Technology, Engineering and Math Teaching Guide. Boston, MA.

Bybee, R. W. (2010). Advancing STEM Education: A 2020 Vision. Technology and Engineering Teacher, 70(1), 30-35.

Campbell, E. (2006). Curricular and Professional Authority in Schools. Curriculum Inquiry, 36(2), 111-118. https://doi.org/10.1111/j.1467-873X.2006.00349.x

Chalufour, I. (2010). Learning to teach science: Strategies that support teacher practice. In Early Childhood Research and Practice. Collected Papers from the STEM in Early Education and Development (SEED) Conference.

Copple, C., \& Bredekamp, S. (2009). Developmentally appropriate practice in early childhood programs serving children from birth through age 8. Washington, DC: National Association for the Education of Young Children.

Early Childhood Education Division (PERMATA) (2013). Kurikulum Permata Negara: Asuhan dan Didikan Awal Kanak-Kanak (0-4 Tahun).

Early Childhood STEM Working Group (2017). Early STEM matters: Providing High-Quality STEM Experiences for All Young Learners. A policy report by Early Childhood STEM working group. Retrieved from http://ecstem.uchicago.edu

Kementerian Pelajaran Malaysia (2013). Pelan Pembangunan Pendidikan Malaysia 2013-2025. Putrajaya: Kementerian Pendidikan Malaysia.

Kumtepe, A.T., \& Genc-Kumtepe, E. (2015). STEM in Early Childhood Education: We Talk the Talk, But Do We Walk the Walk?. In STEM Education: Concepts, Methodologies, Tools, and Applications (pp. 1-24). Hershey, PA: IGI Global. https://doi.org/10.4018/978-1-4666-7363-2.ch001

Ministry of Education Republic of Singapore (2013). Nurturing Early Learners: A Curriculum for Kindergartens in Singapore. Retrieved from http://www.moe.gov.sg/education/preschool

Ministry of Science, Technology and Innovation (MOSTI). (2008). 2008 Report: Malaysian science and technology indicators. Putrajaya: Malaysian Science and Technology Informatio Centre, MOSTI.

Moomaw, S. (2013). Teaching STEM in the early years: Activities for integrating science, technology, engineering, and mathematics. St. Paul, NM: Redleaf Press.

Moomaw, S., \& Davis, J.A.(2010). STEM Comes to Preschool. Young Children, 65(5), 12-14.

Morrison, G. S. (2007). Fundamentals of Early Childhood Education. 5th ed. Upper Saddle River, New Jersey: Pearson Education, INC. 
National Academy of Science (2015). Science and Technology in Human Capital Report and Science Outlook.

NCTM (2002, updated in 2010) Position Statement: Early childhood mathematics: Promoting good beginnings. A joint position statement of the National Association for the Education of Young Children (NAEYC) and the National Council for Teachers of Mathematics (NCTM).

Nordin, K. (2012). Jumlah Pelajar Sains Di IPT Makin Kurang, Berita Harian. Retrieved from http://www.bharian.com.my/articles/JumlahpelajarsainsdiIPTmakinkurang/Article/

Ong, E. T., Ayob, A., Ibrahim, N., Adnan, M., Shariff, J.,\& Mohd. Ishak, N. (2016). Integrating STEM into Early Childhood Education: Is it feasible?. The Eurasia Proceedings of Educationa \& Social Sciences (EPESS), 4, 336-341.

Rhoads, T. R., Walden, S. E., \& Winter, B. A (2004). Sooner Element Engineering and Science (SEES) a model for after school science clubs based on university and K-5 partnership. Journal of STEM education, $5(3), 47-52$

Sanders, M. E. (2009) STEM, STEM Education, STEMmania. The Technology Teacher, 20-26.

Sneideman, J. M (2013). Engaging Children in STEM Education Early! Feature Story. Natural Start Alliance and NAAEE. Retrieved from http://naturalstart.org/feature-stories/engaging-children-stemeducationearly

Soylu, S. (2016). STEM Education in Early Childhood in Turkey. Journal of Educational and Instructional Studies in the World, 6(7), 38-47.

Stevens, D. D., \& Levi, A. J. (2005). Introduction to Rubrics: An Assessment Tool to Save Grading Time, Convey Effective Feedback, and Promote Student Learning. Sterling, VA: Stylus Press.

Weisberg, D. S., Hirsh-Pasek, K., Golinkoff, R. M., Kittredge, A. K., \& Klahr, D. (2016) Guided Play: Principles and Practices. Current Directions in Psychological Science, 25(3), 177-182. https://doi.org/10.1177/0963721416645512

Yoon, J., \& Onchwari, J. (2006) Teaching Young Children Science: Three Key Points. Early Childhood Education Journal, 33(6), 419-423. https://oi.org/10.1007/s10643-006-0064-4 